\title{
Effect of IR Laser on Myoblasts: Prospects of Application for Counteracting Microgravity-Induced Muscle Atrophy
}

\author{
Monica Monici • Francesca Cialdai • \\ Giovanni Romano • Paola Antonia Corsetto • \\ Angela Maria Rizzo • Anna Caselli • Francesco Ranaldi
}

Received: 29 November 2011 / Accepted: 15 October 2012

(C) Springer Science+Business Media Dordrecht 2012

\begin{abstract}
Microgravity-induced muscle atrophy is a problem of utmost importance for the impact it may have on the health and performance of astronauts. Therefore, appropriate countermeasures are needed to prevent disuse atrophy and favour muscle recovery. Muscle atrophy is characterized by loss of muscle mass and strength, and a shift in substrate utilization from fat to glucose, that leads to a reduced metabolic efficiency and enhanced fatigability. Laser therapy is already used in physical medicine and rehabilitation to accelerate muscle recovery and in sports medicine to prevent damages produced by metabolic disturbances and inflammatory reactions after heavy exercise. The aim of the research we present was to get insights on possible benefits deriving from the application of an advanced infrared laser system to counteract deficits of muscle energy metabolism and stimulate the recovery of the hypotrophic tissue. The source used was a Multiwave Locked System (MLS) laser, which combines continuous and pulsed emissions at $808 \mathrm{~nm}$ and $905 \mathrm{~nm}$, respectively. We studied the effect of MLS treatment on morphology and energy metabolism of $\mathrm{C} 2 \mathrm{C} 12$ cells,
\end{abstract}

\footnotetext{
M. Monici ( $\varangle)$ · F. Cialdai · G. Romano

ASAcampus Joint Laboratory, ASA Research Division, ASA- Department Clinical Physiopathology, University of Florence, Viale Pieraccini 6, 50139, Florence, Italy e-mail: monica.monici@unifi.it

P. A. Corsetto - A. M. Rizzo

Dipartimento di Scienze Farmacologiche e Biomolecolari, Università degli Studi di Milano, Milan, Italy

A. Caselli $\cdot$ F. Ranaldi

Department Biochemical Sciences, University of Florence, Florence, Italy
}

a widely accepted myoblast model, previously exposed to microgravity conditions modelled by a Random Positioning Machine. The MLS laser treatment was able to restore basal levels of serine/threonine protein phosphatase activity and to counteract cytoskeletal alterations and increase in glycolytic enzymes activity that occurred following the exposure to modelled microgravity. In conclusion, the results provide interesting insights for the application of infrared laser in the treatment of muscle atrophy.

Keywords Muscle atrophy $\cdot$ Microgravity • Myoblasts · IR laser

\section{Introduction}

Aging and disuse, as occurs in bed rest and spaceflights, induce in skeletal muscle a reductive remodelling and may lead to atrophy. The mechanisms underlying muscle atrophy caused by disuse and muscle aging have some similarities: in both the lack of mechanical stimuli plays a relevant role. In this aspect, conditions associated with muscle disuse, such as the exposure to a weightless environment, are considered a model for studying aging processes in skeletal muscle (Biolo et al. 2003), although other important factors such as changes in the innervation (Doherty 2003) and levels of cytokines and growth factors (Degens 2010) are involved in aging.

Disuse atrophy has been widely studied and is considered a problem of utmost importance in manned spaceflights. It is characterized by loss of muscle mass, force and power, changes in fiber type composition and increased muscle fatigue due to reduced metabolic 
efficiency: a shift in substrate utilization from fat to glucose occurs, leading to an enhanced fatigability (Fitts et al. 2000; Stein and Wade 2005; Blaauw et al. 2010). Hexokinase (HK) activity, considered a marker of glycolytic metabolism, significantly increases (Manchester et al. 1990; Chi et al. 1992). The susceptibility of skeletal muscle to damage increases and becomes particularly evident during postflight reloading (Fitts et al. 2000).

In the future, the increase of mission duration from one side and, from the other side, the expected increase of extravehicular activities, which could require sustained work output, will further exacerbate the problem of managing muscle atrophy during spaceflights and postflight. Therefore, appropriate countermeasures are needed to prevent disuse atrophy and/or favour muscle recovery.

Several studies demonstrated the utility of physical protocols as vibration or electrical stimulation (Chopard et al. 2009; Guo et al. 2012), but too few data regarding the effects of different physical countermeasures on the processes involved in skeletal muscle disuse atrophy and recovery are available.

Due to the proven ability of red-infrared (IR) radiation to enhance cell energy metabolism (Silveira et al. 2009) and reduce inflammation (Rizzi et al. 2006), laser therapy is already used in physical medicine, rehabilitation and sports medicine to accelerate muscle recovery (dos Santos et al. 2010) and to prevent damages produced by metabolic disturbances and inflammatory reactions after heavy exercise (Leal Junior et al. 2009).

This paper reports the results of a study aimed at investigating the effects of IR laser radiation on myoblasts and considering the possibility to apply IR laser therapy to promote muscle regeneration and recovery in disuse atrophy. We used as an experimental model the $\mathrm{C} 2 \mathrm{C} 12$ skeletal muscle cell line, derived from satellite cells. The $\mathrm{C} 2 \mathrm{C} 12$ cells are widely accepted as a model to study the behaviour of satellite cells (Burattini et al. 2004), which play a crucial role in skeletal muscle regeneration and repair (Wang and Rudnicki 2012) and are capable to repopulate atrophied muscle (Hawke and Garry 2001). Moreover, C2C12 cells have been already used in previous studies regarding the effects of microgravity on mechanical signalling mechanisms in muscle plasticity (Torgan et al. 2000) and myoblast behaviour (Slentz et al. 2001; Pache et al. 2010).

Recently, studies in progress in our laboratory, aimed at understanding the cellular and molecular mechanisms underlying the effects of IR laser radiation on repair processes in muscle tissue, demonstrated that $\mathrm{C} 2 \mathrm{C} 12$ cells exposed to IR laser radiation show enhanced cell energy metabolism and a significant increase in serine/threonine protein phos- phatases (PSPs), in particular serine/threonine protein phosphatase 1 (PP1), which plays a crucial role in the regulation of glycogen metabolism and is involved in myosin dephosphorylation, thereby controlling muscle contraction/relaxation (Cohen 2002; Ceulemans and Bollen 2004). Moreover, we observed that proteins involved in cytoskeleton organization/cell shape regulation and muscle contraction, such as vimentin, actin and tropomyosin, also increased (Monici et al. 2012).

Following these findings, we hypothesized that IR laser radiation could be a useful tool to counteract the microgravity-induced impairment of energetic metabolism (Fitts et al. 2000), cytoarchitectural alterations (Pache et al. 2010) and decrease in the levels of contractile proteins (Torgan et al. 2000) observed in myoblasts exposed to microgravity.

Therefore, in myoblasts previously exposed to modelled microgravity, we tested the effect of IR laser treatment on cell metabolism and morphology.

\section{Materials and Methods}

\section{Cell Culture}

Murine myoblasts ( $\mathrm{C} 2 \mathrm{C} 12$ cell line) were routinely cultured in growing medium consisting of Dulbecco's Modified Eagle's Medium supplemented with $100 \mu \mathrm{g} / \mathrm{ml}$ streptomycin, $100 \mathrm{U} / \mathrm{ml}$ penicillin, $2 \mathrm{mM}$ glutamine and $10 \%$ fetal bovine serum (FBS). Cells were incubated at $37{ }^{\circ} \mathrm{C}$ and $5 \% \mathrm{CO}_{2}$. All the reagents have been purchased from Sigma Chemical Co. (St Louis, MO, USA).

\section{MLS Laser Treatment}

The treatments have been performed with an advanced Multiwave Locked System (MLS) laser (ASA Srl), that is a high power (average power up to $1.1 \mathrm{~W}$, class IV) IR laser with two synchronized sources (laser diodes). The two modules have different wavelengths, peak power and emission mode. The first one is a pulsed diode laser, emitting at $905 \mathrm{~nm}$, with peak optical power = $25 \mathrm{~W}$; each pulse is composed of a pulse train (single pulse width $=100 \mathrm{~ns}$, maximum frequency $90 \mathrm{kHz}$ ), thus varying the average power delivered to the tissue. Frequency of the pulse trains may be varied in the range $1-2000 \mathrm{~Hz}$. The second laser diode $(808 \mathrm{~nm})$ operates in continuous mode $(\mathrm{P} 1.1 \mathrm{~W})$ or in pulsed mode (pulses repetition rate 1-2000 Hz), mean optical power output $=550 \mathrm{~mW}$, duty ratio $50 \%$ independently of 
the pulse repetition rate. The two propagation axes are coincident.

For the treatment, cells were seeded in the central 8 wells of a 24-multiwell plate. The plate was placed inside a plexiglass support, specifically designed and built. On the top of the support there was a central groove in which laser handpiece slided. The plate was perfectly aligned with the handpiece, at a distance of $3 \mathrm{~cm}$ from it, so that the spot formed by the two superimposed laser beams had a diameter equal to that of a single well $(13 \mathrm{~mm})$. The support allowed us to perform an homogeneous scan of 8 samples at the same time, by moving the spot at a constant horizontal velocity above the 8 treated wells $(5.6 \mathrm{~cm} / \mathrm{s}$ : each scan of 8 wells lasted $20 \mathrm{~s})$, in order to have the same radiant energy impinging into each well ( $\sim 68 \mathrm{~J}$ for the whole treatment). Treatment parameters were: $1500 \mathrm{~Hz}$ frequency, 8 min total scan time. The scan mode is now extensively used also in clinics because it allows to treat large areas and further contributes to avoid photothermal damage. The treatment was repeated once a day, for 3 consecutive days in sterile conditions. The treated samples were compared with controls maintained in the same conditions, except for the laser exposure.

\section{Random Positioning Machine}

A Random Positioning Machine (RPM) (Dutch Space, Leiden, The Netherlands) was used in order to model unloading conditions.

In the RPM, introduced by Hoson et al. (1997), samples are fixed close to the centre of two frames rotating one inside the other, driven by separate motors. The rotation of each frame is random and autonomous under computer control. The low $g$ conditions are modelled by averaging the gravity vector via the independent rotation of the two frames.

In our experiments, the speed of rotation was $60 \% \mathrm{~s}$ (about $10^{-3} \times g$ ), and direction and interval were set at random. Temperature was maintained at $37^{\circ} \mathrm{C}$. The cells were placed in suitable T25 flasks, which were completely filled with culture medium in order to avoid shear stress, and exposed to the RPM for $72 \mathrm{~h}$.

\section{Study Design}

The following samples were prepared, analyzed and compared:

- Samples exposed to the RPM were compared with the corresponding ones non exposed to the RPM $(1 \times g$ controls $)$.
- Samples exposed to the RPM and then treated with MLS laser were compared with samples exposed to the RPM but untreated with MLS laser.

- $1 \times g$ controls untreated and treated with MLS laser.

$1 \times g$ controls were placed on the fixed base of the RPM, facing the same vibrations and temperature as the rotating ones. At the end of the treatments, the cells were recovered and prepared for analytical tests.

Immunofluorescence Analysis

At the end of the experiments, cells were fixed for $5 \mathrm{~min}$ in cold acetone, then washed in phosphate buffered saline (PBS). After blocking unspecific binding with PBS containing $3 \%$ bovine serum albumin, cells were incubated overnight at $4{ }^{\circ} \mathrm{C}$ with the specific antibodies: anti- $\alpha$ actin, anti-tubulin and anti-vimentin. The cells were then incubated with the fluorescein isothiocyanate (FITC) conjugated specific secondary antibodies (specifically: anti-mouse $\mathrm{IgG}$ for anti-tubulin antibody and anti-mouse $\operatorname{IgM}$ for anti-vimentin antibody). Cells incubated with anti- $\alpha$ actin antibody did not need incubation with the secondary antibody since a mouse anti-actin Alexa Fluor ${ }^{\circledR} 488$ conjugated was used. All antibodies were purchased from Chemicon Int, (Temecula, CA). Negative controls were obtained by omitting the primary antibodies. Samples were evaluated by an epifluorescence microscope (Nikon, Florence, Italy) at $100 \times$ magnification and imaged by a HiRes IV digital CCD camera (DTA, Pisa, Italy).

\section{Cell Lysis}

Cells were quickly rinsed in ice-cold phosphatebuffered saline (PBS, $10 \mathrm{mM}$ sodium phosphate and $0.15 \mathrm{M} \mathrm{NaCl}, \mathrm{pH} 7.2$ ), and frozen at $-80{ }^{\circ} \mathrm{C}$. After thawing the material at room temperature, the lysis was performed at $4{ }^{\circ} \mathrm{C}$ in $50 \mathrm{mM}$ Tris, $\mathrm{pH} 7.4$, containing $5 \mathrm{mM}$ ditiothreitol and Sigma protease inhibitors mix $(1 / 100, \mathrm{v} / \mathrm{v})$. After $30 \mathrm{~min}$ of incubation on ice, lysates were sonicated (three short bursts) and centrifuged at $12,000 \mathrm{~g}$ in a microcentrifuge at $4{ }^{\circ} \mathrm{C}$ for $30 \mathrm{~min}$. Supernatants were quantified with respect to protein content by Bradford method.

\section{Determination of Total Protein Concentration}

Total protein concentration was determined according to the Bradford's method (1976), using a kit (Bradford 
Reagents) produced by Sigma Chemical Co. (St Louis, MO, USA).

\section{Determination of Pyruvate Kinase Activity}

Pyruvate kinase (PK) activity was determined at $37^{\circ} \mathrm{C}$ according to Hess and Wieker (1974), with slight modifications, continuously following NADPH oxidation at $340 \mathrm{~nm}$, by using an UV-2100 spectrophotometer (Shimadzu, Columbia, MD). The assay mixture contained in $1 \mathrm{ml}$ final volume consisted of $50 \mathrm{mM}$ triethanolamine ( $\mathrm{pH} 7.6$ ), $8 \mathrm{mM} \mathrm{MgSO}_{4}, 5 \mathrm{mM}$ EDTA, $75 \mathrm{mM} \mathrm{KCl}, 1.5 \mathrm{mM}$ ADP, $0.15 \mathrm{mM}$ NADH, $5 \mathrm{mg} / \mathrm{ml}$ lactate dehydrogenase.

The reaction was started by adding the substrate $(0.8 \mathrm{mM}$ phosphoenolpyruvate). The value of $6.22 \mathrm{mM}^{-1} \mathrm{~cm}^{-1}$ is considered to be the NADH (or NADPH) molar extinction co-efficient. One unit of activity is defined as the quantity of enzyme which transforms $1 \mu$ mole of substrate in $1 \mathrm{~min}$, at $30^{\circ} \mathrm{C}$.

\section{Determination of Hexokinase Activity}

HK activity was determined at $37{ }^{\circ} \mathrm{C}$ according to Bergmeyer (1974), with slight modifications, continuously following the formation of NADPH at $340 \mathrm{~nm}$, by using an UV-2100 spectrophotometer (Shimadzu, Columbia, MD). The assay mixture contained in $1 \mathrm{ml}$ final volume consisted of $50 \mathrm{mM}$ triethanolamine (pH 7.6), $8 \mathrm{mM} \mathrm{MgSO}_{4}, 5$ mM EDTA, $1.5 \mathrm{mM}$ ATP, $0.2 \mathrm{mM}$ NADP, $2 \mathrm{mg} / \mathrm{ml}$ glucose-6-phosphate dehydrogenase. The reaction was started by adding the substrate (0.4 mM glucose).

Determination of Serine/Threonine Protein Phosphatase Activity

Protein serine/threonine phosphatase (PSPs) activity was determined using $p$-nitrophenyl phosphate as a substrate. The substrate $(4 \mathrm{mM})$ was dissolved in $25 \mathrm{mM}$ Tris-HC1 buffer, $\mathrm{pH} 7.2$, containing $5 \mathrm{mM}$ ditiothreitol, $20 \mathrm{mM}$ sodium-potassium DL-tartrate, and $0,1 \mathrm{mM}$ Sodium orthovanadate. Tartrate and orthovanadate were added in order to inhibit protein tyrosine phosphatases, lysosomal acid phosphatases and non-specific phosphatases (Walton and Dixon 1993). The reaction was stopped with $0.1 \mathrm{M} \mathrm{KOH}$ and the released $\mathrm{p}$-nitrophenolate ion was measured by reading the absorbance at $400 \mathrm{~nm}\left(\varepsilon=18,000 \mathrm{M}^{-1} \mathrm{~cm}^{-l}\right)$. The activity measured in these conditions was completely inhibited by $10 \mu \mathrm{M}$ cantharidic acid, a specific and strong inhibitor of all PSPs (Knapp et al. 1998).
Statistics

Experiments were carried out in triplicate. For immunofluorescence analysis, at least 30 cells per slide were scored in 10 random fields/slide, and the data were expressed as mean $\pm \mathrm{SD}$. Statistical significance was determined using a Student's t test. A $p$ value lower than 0.05 was considered statistically significant.

\section{Results}

In all the samples, the total protein content was analyzed and then used to normalize the measurements of enzymatic activities. The results show that the $1 \times g$ control samples, both laser-treated and untreated, had a similar protein content. The protein content was reduced of about $40 \%$ in the samples exposed to the RPM, but increased fivefold in samples exposed to the RPM and then treated with MLS laser (Fig. 1).

The HK activity, considered a marker of glycolytic metabolism (Grichko et al. 2000), did not show significant changes in $1 \times g$ controls exposed to MLS laser, in comparison with untreated $1 \times g$ controls. Myoblasts kept on the RPM showed a HK activity sevenfold higher than $1 \times g$ controls, but in the samples exposed to modelled microgravity and then to MLS laser irradiation the enzyme activity strongly decreased (Fig. 2a). Also PK activity increased (30\%) in modelled microgravity and decreased (84\%) after the laser treatment (Fig. 2b). Serine/threonine protein phosphatase (PSPs)

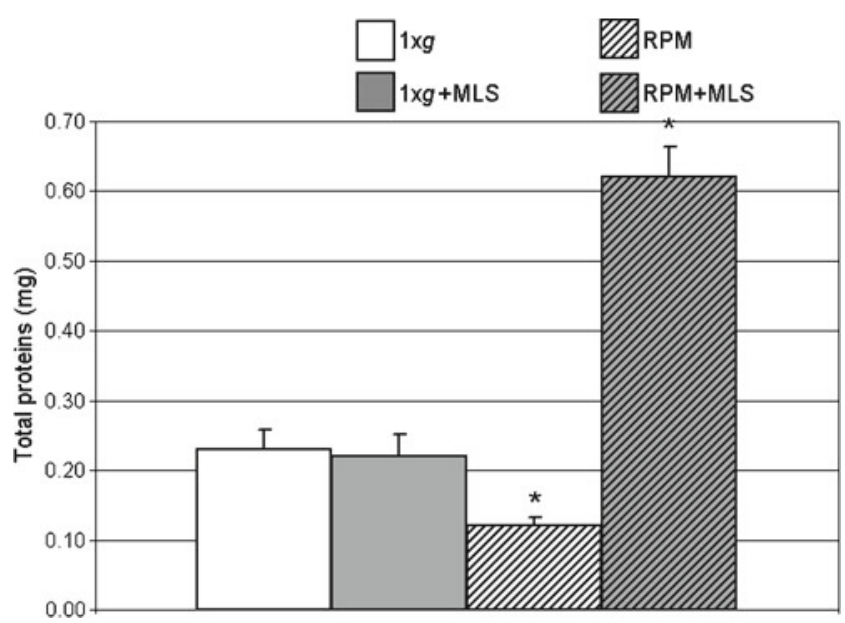

Fig. 1 Analysis of total protein content $-1 \times g$ control samples, both laser-treated and untreated, showed a similar protein content. It decreased significantly in the samples exposed to the RPM for $72 \mathrm{~h}$, but strongly increased in samples exposed to the RPM and then treated with MLS laser. The symbol "*" indicates a $p$ value lower than 0.05 


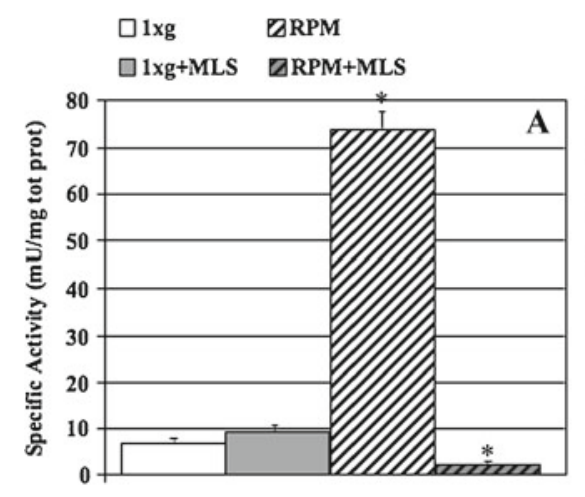

Fig. 2 a Hexokinase activity - The HK activity did not change significantly in the $1 \times g$ controls exposed to MLS laser, in comparison with the untreated ones. Myoblasts exposed to modelled microgravity (RPM) showed an impressive increase in HK activity. In the samples exposed to modelled microgravity, and then to MLS laser irradiation, the enzyme activity decreased to values

activity appeared more than doubled in laser-treated $1 \times g$ controls, in comparison with the untreated ones. In $\mathrm{C} 2 \mathrm{C} 12$ cells exposed to gravitational unloading PSPs activity dramatically fell down, but went up significantly in cells treated with MLS laser after the exposure to modelled microgravity conditions (Fig. 3).

The morphological analysis of the three major components of cytoskeleton, actin microfilaments, microtubules and intermediate filament network, which was performed by immuno-fluorescence microscopy, showed evident architectural alterations of all the three

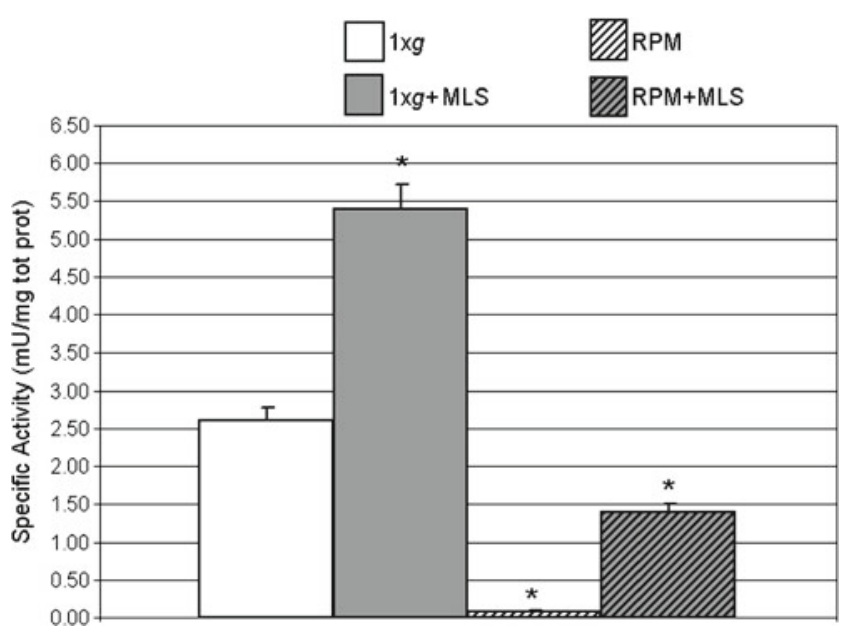

Fig. 3 Serine/threonine protein phosphatase activity-PSPs activity increased in laser-treated $1 \times g$ controls, in comparison with the untreated ones. In $\mathrm{C} 2 \mathrm{C} 12$ cells exposed to gravitational unloading, PSPs activity dramatically decreased, but increased significantly in cells treated with MLS laser after the exposure to modelled microgravity conditions. The symbol "*” indicates a $p$ value lower than 0.05

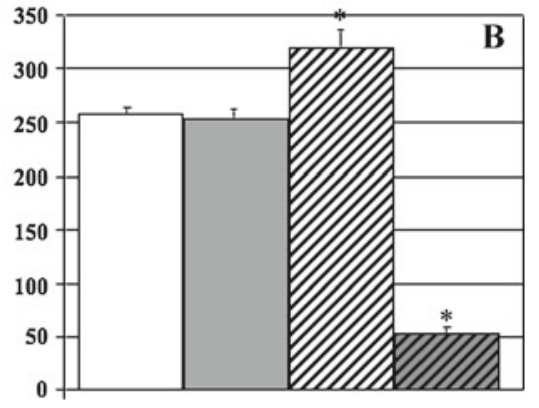

lower than $1 \times g$ controls. b Pyruvate Kinase activity-Also PK activity increased (30\%) in modelled microgravity and decreased $(84 \%)$ after the laser treatment. No differences were observed between the $1 \times g$ controls untreated and treated with MLS laser. The symbol "*" indicates a $p$ value lower than 0.05

cytoskeletal structures examined in the samples kept in the RPM: in comparison with $1 \times \mathrm{g}$ controls, the actin expression in the cytoplasm decreased while stress fibers became more evident and microspikes with high actin expression appeared on the cell surface (Fig. 4c); the intermediate filaments lost the orderly perinuclear arrangement and concentrated at the center of the cell partially covering the nucleus (Fig. 4g), microtubules lost the usual radial distribution starting from the organization centre but formed a tangled network (Fig. 4k). No significant differences were found between lasertreated and untreated $1 \times g$ controls (Fig. 4a, b, c, f, $i, j)$. The samples exposed to modelled microgravity and then to the laser treatment showed a cytoskeletal structure restored and more similar to the $1 \times \mathrm{g}$ controls than the samples kept in RPM without subsequent laser treatment (Fig. 4d, h, l).

\section{Discussion}

In literature, the data on protein content in muscle cells exposed to weightlessness are controversial and very difficult to compare because the authors used different times of exposure (from minutes to days), different models (myoblasts, muscle fibers, 2D cultures or 3D cultures), real or modelled microgravity and, in this last case, different devices for modelling microgravity (random positioning machine, rotating wall vessel). Likely, the different results depend on the different experimental conditions and models used.

The decrease in total protein content we observed in the samples exposed to modelled microgravity conditions (Fig. 1) could be due to many processes: an 


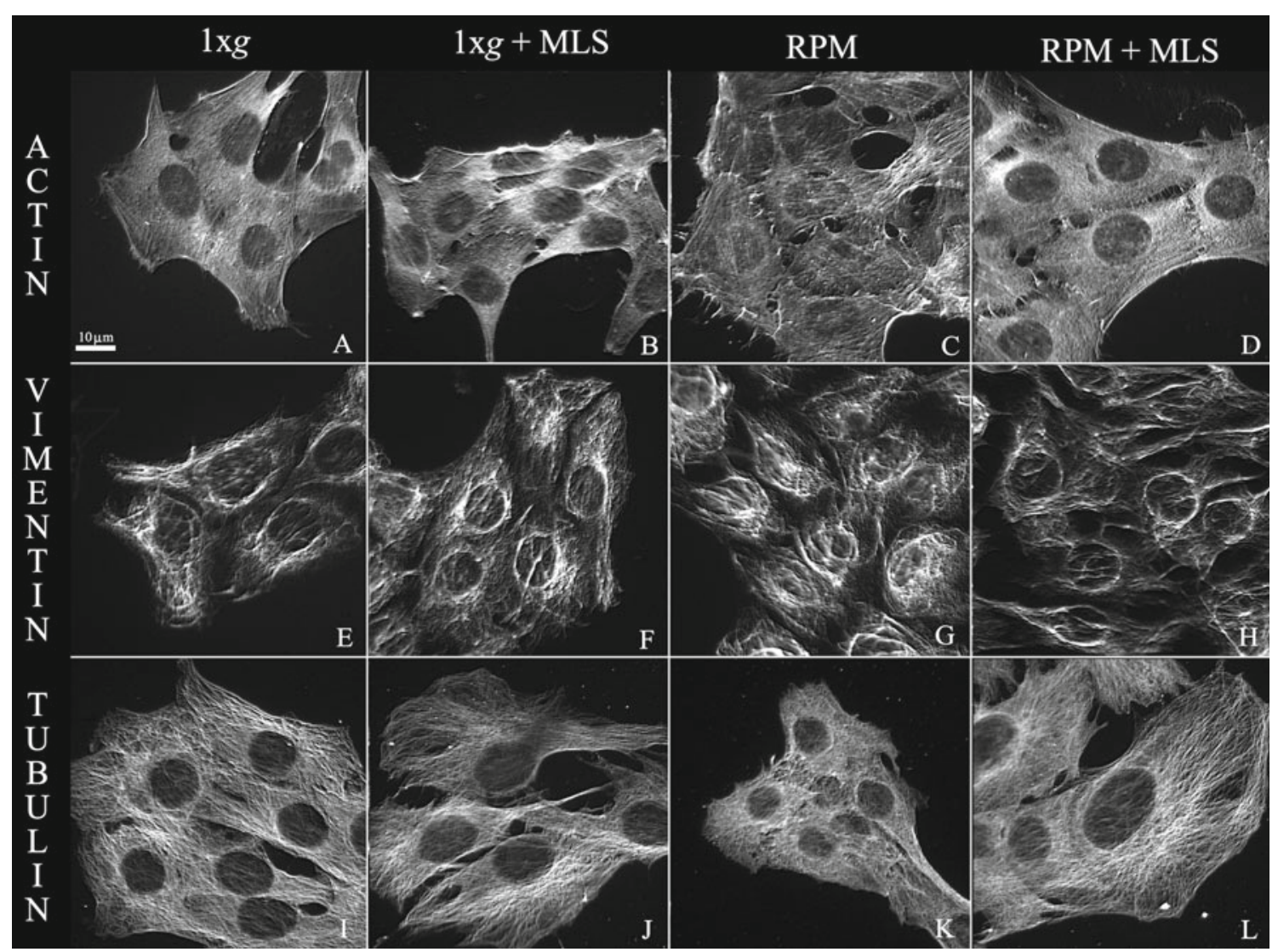

Fig. 4 Cytoskeleton components analyzed by immunofluorescence microscopy-Samples exposed to modelled microgravity $(\mathbf{c}, \mathbf{g}, \mathbf{k})$, compared to $1 \times g$ controls, showed evident architectural alterations of the three major cytoskeleton components: actin microfilaments, intermediate filaments and microtubules. Actin stress fibers became more evident and microspikes with high actin expression appeared on the cell surface (c); the intermediate filaments lost the orderly perin-

increase in apoptosis, which often occurs in cell cultures exposed to weightless conditions (Uva et al. 2002; Monici et al. 2006), a microgravity-induced decrease in myoblast proliferation, which has been recently found by other authors (Pache et al. 2010), altered protein synthesis/degradation (Moriggi et al. 2010), or a combination of these effects.

In agreement with data presented by other authors (Shimkus et al. 2011), preliminary experiments we performed did not reveal significant changes in proliferation and apoptosis induced by exposure to modelled microgravity. Some authors have found an increase (Slentz et al. 2001) or a decrease (Pache et al. 2010) in proliferation using different exposure times and conditions for simulating microgravity. Thus, in our experimental conditions, we are inclined to think that the decrease in total protein content depends on an altered protein synthesis/degradation. uclear arrangement and concentrated at the center of the cell partially covering the nucleus (g), microtubules lost the usual radial distribution starting from the organization centre but formed a tangled network (k). No significant differences were found between untreated and laser-treated $1 \times g$ controls $(\mathbf{a}, \mathbf{b}, \mathbf{c}$, $\mathbf{f}, \mathbf{i}, \mathbf{j})$. The samples exposed to modelled microgravity and then to the laser treatment showed a cytoskeletal structure restored and similar to the $1 \times g$ controls $(\mathbf{d}, \mathbf{h}, \mathbf{l})$

As expected, a strong increase in HK activity was found in RPM-exposed cells and also PK activity increased (Fig. 2a and b). These results fit very well with data reported in literature: after spaceflights and bed rest, an upregulation of glycolytic enzymes, in particular HK and PK levels, has been described by several authors (Chi et al. 1992; Stump et al. 1997; Stein et al. 2002) and represents a clear sign of microgravityinduced metabolic impairment. In myoblasts exposed to modelled microgravity, besides the decrease in total protein content and increase in glycolytic enzyme levels, the PSPs activity dramatically fell down (Fig. 3).

Despite the crucial role PSPs have in signal transduction and biological functions, the effect of the gravitational conditions on their expression and activity has been relatively little studied. PSPs, by opposing the action of protein kinases, regulate protein phosphorilation and therefore control metabolism and basical 
processes such as protein-protein interactions, gene transcription and translation, cell-cycle progression and apoptosis, cytoskeleton dynamics and cell movement (Berridge 2009).

Our results suggest that the dysregulation of HK (and other glycolytic enzymes) could be related to the impressive reduction of PSPs activity, since it has been recently demonstrated in skeletal muscles of freezetolerant frogs that HK can be dephosphorilated by PP1 and, in this form, displays lower substrate affinity and lower activity (Dieni and Storey 2011).

The deficit in PSPs activity could be also involved in the cytoskeletal alterations induced in myoblasts by weightlessness (Fig. 4c, g, k) and described also by other authors (Pache et al. 2010). In fact it is known that PSPs, and particularly PP1, are involved in actin and actomiosin reorganization, regulation of cell shape and cell adhesion (Cohen 2002; Ceulemans and Bollen 2004).

Finally, a low PSPs activity could have altered protein turnover (Ceulemans and Bollen 2004), thus affecting protein content.

MLS laser irradiation induced in $1 \times g$ controls a significant increase in PSPs activity (Fig. 3), confirming the results we obtained in preliminary studies on the effect of MLS emission on muscle cells, where we found an significant increase in PSPs expression, foremost the expression of PP1 (Monici et al. 2012). In the same samples, protein content, $\mathrm{HK}$ and $\mathrm{PK}$ activities did not change significantly.

In myoblast cultures previously exposed to microgravity, the laser treatment was able to restore, at least partially, the level of PSPs activity (Fig. 3). Moreover, protein content strongly increased (Fig. 1) and both HK and PK activities returned to levels comparable to those expressed by the $1 \times g$ controls, or even lower (Fig. $2 \mathrm{a}$ and $\mathrm{b}$ ).

These results support the hypothesis that, in myoblasts exposed to modelled microgravity conditions, a relationship could exist between the downregulation of PSPs activity and alteration of metabolism markers. Moreover, as we hypothesized, in myoblasts previously kept in the RPM, MLS laser treatment, through the increase of PSPs activity, was able to reverse the metabolic alterations induced by modelled microgravity.

Our findings completely fit with the actual knowledge on the function of PSPs and, in particular, the role of PP1. In a recent review PP1 has been defined a "green" enzyme that promotes the rational use of energy and a reversal of the cell to a basal and/or energy-conserving state, the recycling of protein factors and the return to basal patterns of protein synthesis; in addition, PP1 plays a key role in the recovery from stress (Ceulemans and Bollen 2004).

The results obtained by analyzing cell morphology further confirm our hypothesis. In fact, as expected, C2C12 cells exposed to modelled microgravity showed an evident reorganization of cytoskeleton, with architectural features of the networks of microfilaments, microtubules and intermediate filaments very different from $1 \times g$ controls. Conversely, myoblasts treated with MLS laser after RPM exposure exhibited a cytoskeletal architecture very similar to that of the $1 \times g$ controls. This faster return to the basic morphological pattern fits very well with the widely recognized role of PSPs in cytoskeletal rearrangement.

To the best of our knowledge this is the first time that a decrease in PSPs activity in myoblasts exposed to weightlessness is described and the ability of IR laser radiation to reverse the effect is demonstrated.

In conclusion, the MLS laser treatment was able to restore the level of PSPs activity and to counteract increase in glycolytic enzymes activity and cytoskeletal alterations that occurred in $\mathrm{C} 2 \mathrm{C} 12$ cells following the exposure to modelled microgravity.

While taking into account the limitation of the present data on myoblasts with respect to the interpretation for mature muscle fibers, however the results suggest that changes in PSPs activity could underlie some effects induced by microgravity in skeletal muscle cells. Moreover, the possibility of reversing the effects by laser treatment opens the way to considerations about the usefulness of laser therapy to favour muscle recovery in disuse atrophy.

The findings of this "in vitro" study represent only a preliminary step in exploring the effectiveness of laser therapy as a countermeasure to disuse atrophy. However, in our opinion, they provide original insights that encourage further research in this field.

\section{References}

Bergmeyer, H.U.: Methods of Enzymatic Analysis, 2nd edn., vol. 1, pp. 473-474. Academic Press, New York (1974)

Berridge, M.J.: Cell Signalling Biology, OFF Mechanisms, Protein Phosphatases. Portland Press (2009)

Biolo, G., Heer, M., Narici, M., Strollo, F.: Microgravity as a model of ageing. Curr. Opin. Clin. Nutr. Metab. Care 6, 3140 (2003)

Blaauw, B., Reggiani, C., Schiaffino, S.: Effect of loading and unloading on skeletal muscle. In: Monici, M., van Loon, J. (eds.) Cell Mechanochemistry. Biological Systems and Factors Inducing Mechanical Stress, such as Light, Pressure and Gravity, pp. 153-183. Research Signpost/Transword Research Network, Trivandrum, India (2010) 
Bradford, M.: A rapid and sensitive method for the quantitation of microgram quantities of protein utilizing the principle of protein-day binding. Anal. Biochem. 72, 248-254 (1976)

Burattini, S., Ferri, P., Battistelli, M., Curci, R., Luchetti, F., Falcieri, E.: $\mathrm{C} 2 \mathrm{C} 12$ murine myoblasts as a model of skeletal muscle development: morpho-functional characterization. Eur. J. Histochem. 48(3), 223-234 (2004)

Ceulemans, H., Bollen, M.: Functional diversity of protein phosphatase-1, a cellular economizer and reset button. Physiol. Rev. 84, 1-39 (2004)

Chi, M.M., Choksi, R., Nemeth, P., Krasnov, I., Ilyina-Kakueva, E., Manchester, J.K., Lowry, O.H.: Effects of microgravity and tail suspension on enzymes of individual soleus and tibialis anterior fibers. J. Appl. Physiol. 73(2 Suppl), 66S-73S (1992)

Chopard, A., Hillock, S., Jasmin, B.J.: Molecular events and signalling pathways involved in skeletal muscle disuse-induced atrophy and the impact of countermeasures. J. Cell. Mol. Med. 13(9B), 3032-3050 (2009)

Cohen, P.T.W.: Protein phosphatase 1 - targeted in many directions. J. Cell Sci. 115, 241-256 (2002)

Degens, H.: The role of systemic inflammation in age-related muscle weakness and wasting. Scand. J. Med. Sci. Spor. 20, 28-38 (2010)

Dieni, C.A., Storey, K.B.: Regulation of hexokinase by reversible phosphorylation in skeletal muscle of a freeze-tolerant frog. Comp. Biochem. Physiol. B 159, 236-243 (2011)

Doherty, T.J.: Aging and sarcopenia. J. Appl. Physiol. 95, 1717$1727(2003)$

dos Santos, D.R., Liebano, R.E., Baldan, C.S., Masson, I.B., Soares, R.P., Esteves, I.J.: The low-level laser therapy on muscle injury recovery: literature review. J. Health Sci. Inst. 28(3), 286-288 (2010)

Fitts, R.H., Riley, D.R., Widrick J.J.: Physiology of a microgravity environment, invited review: microgravity and skeletal muscle. J. Appl. Physiol. 89, 823-839 (2000)

Grichko, V.P., Heywood-Cooksey, A., Kidd, K.R., Fitts, R.H.: Substrate profile in rat soleus muscle fibers after hindlimb unloading and fatigue. J. Appl. Physiol. 88, 473-478 (2000)

Guo, B.S., Cheung, K.K., Yeung, S.S., Zhang, B.T., Yeung, E.W.: Electrical stimulation influences satellite cell proliferation and apoptosis in unloading-induced muscle atrophy in mice. PLoS One 7(1), e30348 (2012). doi:10.1371/journal.pone. 0030348

Hawke, T.J., Garry, D.J.: Myogenic satellite cells: physiology to molecular biology. J. Appl. Physiol. 91, 534-551 (2001)

Hess, B., Wieker, H.J.: Methods for determination of enzyme activity: pyruvate kinase. In: Bergmeyer, H.U. (ed.) Methods of enzymatic analysis, 2nd edn., vol. 2, pp. 778-783. Academic Press, Inc, New York (1974)

Hoson, T., Kamisaka, S., Masuda, Y., Yamashita, M., Buchen, B.: Evaluation of the three-dimentional clinostat as a simulator of weightlessness. Planta 203, S187-S197 (1997)

Knapp, J., Boknìk, P., Huke, S., Gombosovà, I., Linck, B., Lüss, H., Müller, F.U., Müller, T., Nacke, P., Schmitz, W., Vahlensieck, U., Neumann, J.: Contractility and inhibition of protein phosphatases by cantharidin. Gen. Pharm. 31(5), 729-733 (1998)

Leal Junior, E.C.P., Lopes-Martins, R.A.B., Baroni, B.M., De Marchi, T., Taufer, D., Manfro, D.S., Rech, M., Danna, V., Grosselli, D., Generosi, R.A., Marcos, R.L., Ramos, L., Bjordal, J.M.: Effect of $830 \mathrm{~nm}$ low-level laser therapy applied before high-intensity exercises on skeletal muscle recovery in athletes. Lasers Med. Sci. 24, 857-863 (2009)

Manchester, J.K., Chi, M.M., Norris, B., Ferrier, B., Krasnov, I., Nemeth, P.M., McDougal, D.B. Jr., Lowry, O.H.: Effect of microgravity on metabolic enzymes of individual muscle fibers. FASEB J. 4(1), 55-63 (1990)

Monici, M., Fusi, F., Paglierani, M., Marziliano, N., Cogoli, A., Pratesi, R., Bernabei, P.A.: Modeled gravitational unloading triggers differentiation and apoptosis in preosteoclastic cells. J. Cell. Biochem. 98(1), 65-80 (2006)

Monici, M., Cialdai, F., Ranaldi, F., Boscaro, F., Moneti, G., Caselli, A.: Effect of IR laser on myoblasts: a proteomic study. VII ItPA Annual Congress, Viterbo, 2012, ABS034, p. 33 (2012)

Moriggi, M., Vasso, M., Fania, C., Capitanio, D., Bonifacio, G., Salanova, M., Blottner, D., Rittweger, J., Felsenberg, D., Cerretelli, P., Gelfi, C.: Long term bed rest with and without vibration exercise countermeasures: effects on human muscle protein dysregulation. Proteomics 10(21), 3756-3774 (2010)

Pache, C., Kühn, J., Westphal, K., Jérôme Parent, M.F.T., Franco-Obregón, O.B.A., Depeursinge, C., Egli, M.: Digital holographical microscopy real-time monitoring of cytoarchitectural alterations during simulated microgravity. J. Biomed. Opt. 15(026021), 1-9 (2010)

Rizzi, C.F., Mauriz, J.L., Sousa, D., Correa, F., Moreira, A.J., Zettler, C.G., Filippin, L.I., Marroni, N.P., GonzalezGallego, J.: Effects of Low-Level Laser Therapy (LLLT) on the Nuclear Factor (NF)-kB signaling pathway in traumatized muscle. Laser. Surg. Med. 38, 704-713 (2006)

Shimkus, K.L., Zanello, S., Emami, K., Wu, H.: Simulated Microgravity does not Alter Myogenesis Gene Expression in C2C12 Cells. 18th IAA Humans in Space Symposium, Houston, Texas, USA. Abstract 2238 (2011)

Silveira, P.C., Silva, L.A., Fraga, D.B., Freitas, T.P., Streck, E.L., Pinho, R.: Evaluation of mitochondrial respiratory chain activity in muscle healing by low-level laser therapy. J. Photoch. Photobio. B 95, 89-92 (2009)

Slentz, D.H., Truskey, G.A., Kraus, W.E.: Myogenic satellite cells: physiology to molecular biology. J. Appl. Physiol. 91, 534-551 (2001)

Stein, T.P., Schluter, M.D., Galante, A.T., Soteropoulos, P., Tolias, P.P., Grindeland, R.E., Moran, M.M., Wang, T.J., Polansky, M., Wade, C.E.: Energy metabolism pathways in rat muscle under conditions of simulated microgravity. J. Nutr. Biochem. 13, 471-478 (2002)

Stein, T.P., Wade C.E.: Metabolic consequences of muscle disuse atrophy. J. Nutr. 1824S-1828S (2005)

Stump, C.S., Tipton, C.M., Henriksen, E.J.: Muscle adaptations to hindlimb suspension in mature and old Fischer 344 rats. J. Appl. Physiol. 82, 1875-1881 (1997)

Torgan, C.E., Burge, S.S., Collinsworth, A.M., Truskey, G.A., Kraus, W.E.: Differentiation of mammalian skeletal muscle cells cultured on microcarrier beads in a rotating cell culture system. Med. Biol. Eng. Comput. 38(5), 583-590 (2000)

Uva, B.M., Masini, M.A., Sturla, M., Prato, P., Passalacqua, M., Giuliani, M., Tagliaferro, G., Strollo, F.: Clinorotationinduced weightlessness influences the cytoskeleton of glial cells in culture. Brain Res. 934, 132-139 (2002)

Walton, K.M., Dixon, J.E. Protein tyrosine phosphatises. Annu. Rev. Biochem. 62, 101-120 (1993)

Wang, Y.X., Rudnicki, M.A.: Satellite cells, the engines of muscle repair. Nat. Rev./Mol. Cell Biol. 13, 127-133 (2012) 